\title{
Comparative evaluation of water budgeting parameters under different rice (Oryza sativa L.) cultivation methods
}

\author{
Sagar Dattatraya Vibhute ${ }^{*}$, A. Sarangi ${ }^{2}$, D. K. Singh ${ }^{2}$, K. K. Bandhyopadhyay ${ }^{3}$, S. S. \\ Parihar $^{2}$ and Dinesh Kumar ${ }^{4}$ \\ ${ }^{1 *}$ Division of Agricultural Engineering,Indian Council of Agricultural Research -IndianAgricultural Research Insti- \\ tute (ICAR-IARI), New Delhi- 110012, INDIA \\ ${ }^{2}$ Water Technology Centre, ICAR-IARI, New Delhi - 110012, INDIA \\ ${ }^{3}$ Division of Agricultural Physics, ICAR-IARI, New Delhi - 110012, INDIA \\ ${ }^{4}$ Division of Agronomy, ICAR-IARI, New Delhi - 110012, INDIA \\ *Corresponding author. E-mail: vibhutesagar5@gmail.com
}

Received: August 31, 2016; Revised received: February 17, 2017; Accepted: July 7, 2017

\begin{abstract}
Water budgeting studies under different rice cultivation methods provides an insight into the amount of water used by the plant and percolated below the root zone for judicious water management. To undertake this study, a field experiment was conducted to estimate different soil water balance parameters under three rice (Oryza sativa L.) cultivation methods viz. Direct Seeded Rice (DSR), System of Rice Intensification (SRI) and Conventional Puddled Rice (CPR). The experiment was conducted during kharif 2013 and kharif 2014 season at research farm of Indian Council of Agricultural Research-Indian Agricultural Research Institute, New Delhi, India. In this study, the rainfall and irrigation depth, Crop Evapotranspiration $\left(E T_{c}\right)$, percolation beyond root zone of the crop and surface runoff during the crop growth period were accounted in water budgeting. It was observed that the percolation beyond root zone of the crop was the highest under CPR method amounting $963 \mathrm{~mm}$ and $831 \mathrm{~mm}$, which was about $55 \%$ and $58 \%$ of total water applied during 2013 and 2014 , respectively. However, the percolation beyond root zone of the crop was the lowest under DSR method of rice cultivation amounting $367 \mathrm{~mm}$ and $332 \mathrm{~mm}$ which was $43 \%$ and $39 \%$ of total water applied during 2013 and 2014, respectively. Water loss through $\mathrm{ET}_{\mathrm{c}}$ was around $30 \%$ of total water applied in all three cultivation methods for year 2013 . However, it was $59 \%, 46 \%$ and $43 \%$ of total water applied for DSR, SRI and CPR, respectively in the year 2014.This indicates more effective utilization of total applied water in the year 2014. The study highlighted that water loss through deep percolation beyond root zone is the major factor contributing to the high water requirement in CPR and SRI methods compare to DSR method. Moreover,different soil water balance components computed in this study will be helpful for estimation of irrigation water requirement in the rice growing areas of the agro-climatic region VI (Trans-gangetic Plains) of India.
\end{abstract}

Keywords: Direct seeded rice, Conventional puddled rice, System of rice intensification, Water budgeting

\section{INTRODUCTION}

Rice (Oryza sativa L.) is an important cereal crop of developing countries and staple food of more than half of the world's population (Fagaria, 2007). In India, rice is grown on 44 million hectare area and contributes to 41.5 per cent of total food grain production of the country(Anonymous, 2016). Moreover, due to higher irrigation water requirement of rice as compared to other cereal crops, water-saving irrigation technologies assumes importance to deal with water scarcity and its sustainability (Li and Barker, 2004). There are various water-saving technologies which help to cope with water scarcity in irrigated environments. These watersaving technologies enhance the water productivity by reducing unproductive seepage and percolation losses, and to a lesser extent by reducing evaporation (Boumanet al., 2005). In India, rice is mainly grown under three cultivation methods viz.Conventional Puddled Rice (CPR), Direct Seeded Rice (DSR) and System of Rice Intensification (SRI). The DSR method of rice establishment is taken up to minimize outflows from the rice field by growing the crop as upland crop like wheat or maize. In this system, the rice is grown in non-puddled and non-saturated soil (i.e., aerobic condition) without flooding the field. Bouman (2007) observed that, when rice is grown as an upland crop in areas with high seepage and percolation rates, a large amount of water is being saved at the field level. DSR rice farming is very effective in minimizing water losses by seepage, percolation and evaporation and saves considerable amount of water used for puddling activity besides restoration of soil structure which gets affected due to puddling activities in SRI and conventional puddled cultivation methods.

A fundamental part of understanding and improving 
agricultural water management is quantitative estimation of major components of field water balance under different crops. The concept of water balance is one of the greatest advances in understanding the response of crops grown in limited water availability situations (Angus, 1991). Soil water budgeting under cropped environment which is similar to a financial statement of income and expenditure takes into account all inputs sources of water besides the water removed or stored in a given volume of soil for a given crop during a given period of time. The soil water balance equation thus helps in making estimates of parameters, which influence the amount of soil moisture available within the crop root zone. Quantification of irrigation water in terms of its utilized and un-utilized components is a useful procedure to minimize the wastage of water. An understanding of water balance is necessary to appreciate the role of different agricultural water management strategies to minimize the losses and maximize its utilization, which is the most limiting factor of crop production in semi-arid tropics. Dash et al. (2014) observed that in irrigated puddled paddy fields only less than half of the added water was utilized by the crop with $55.6 \%$ of supplied water lost through percolation below root zone. Sandhu et al. (2012) conducted an experiment at the institute farm of Punjab Agriculture University, Ludhiana, during kharif seasons of 2009 and 2010 to evaluate water saving techniques in rice cultivation. The experiment was undertaken with two methods of planting (i.e. transplanting on slopes of fresh bed and transplanting in puddled flat plots). Transplanting rice seedlings on slopes of freshly constructed beds resulted in $15 \%$ saving of irrigation water as compared to puddled. Linquistet al. (2015) studied water balance and evapotranspiration in Dry Seeded(DS) and Wet Seeded (WS) rice systems in which the $\mathrm{ET}_{\mathrm{c}}$ and water use were observed to be lower in DS systems as compared to WS systems under one irrigation treatment during initial crop growth stages. However, no significant different in total water use was observed for both DS and WS systems under two or three irrigation treatments at subsequent growth stages. Review of research work pertaining to water budgeting estimates in rice reveled that there is absence of any comparative evaluation of water budgeting parameters in three different rice cultivation methods under irrigated environment. Therefore, an attempt was made in this study to estimate different water balance parameters under DSR, SRI and conventional puddled method of rice cultivation through data acquisition and analysis from experimental field during kharif 2013 and 2014.

\section{MATERIALS AND METHODS}

Study area: Field experiment was conducted during kharif seasons of year 2013 and 2014 at 14-C block of the research farm of the Indian Council of Agricul- tural Research - Indian Agricultural Research Institute (ICAR-IARI), New Delhi, India. The farm is located at $28^{\circ} 36^{\prime} \mathrm{N}$ latitude and $77^{\circ} 12^{\prime} \mathrm{E}$ longitudes at an elevation of $228 \mathrm{~m}$ from mean sea level. The climate of the area is semi-arid with an average annual temperature of $25^{\circ} \mathrm{C}$ and average annual rainfall of $650 \mathrm{~mm}$. The soil texture of experimental plot was silty loam. The average groundwater table depth in the area was at $18 \mathrm{~m}$ from ground surface during the study period.

Experimental design: Design of field experiment adopted in the study was a split plot design with three replications (Fig. 1). The main plot contained different methods of cultivation and the sub plots were two different rice cultivars under adequate and deficit irrigation water regimes. . In year 2013, two rice cultivars viz. PRH-10 and PUSA 1460 were cultivated while in year 2014, Pusa Sugandh 5 and PUSA 1509 were cultivated in different methods of cultivation viz. Direct Seeded Rice (DSR), System of Rice Intensification (SRI) and Conventional Puddled Rice (CPR) under adequate and deficit irrigation regimes. Standard agronomic package and practices were adopted for these three cultivation methods and periodic data of soil moisture, plant and irrigation water depths were recorded to undertake the water budgeting analysis under full irrigation regime. The water balance and yield parameters under adequate irrigation treatment and two cultivars (PRH 10 for 2013 and Pusa Sugandh 5 for 2014) are presented in this study.

Soil sampling and analysis: Soil samples were collected from experimental plots before transplanting and after harvesting for CPR method to estimate the soil moisture status during the plant growth period. In case of SRI and DSR methods of cultivation, soil samples were collected and analyzed before and after every irrigation event. Soil physical parameters of the experimental field were determined in laboratory (Bouyoucos, G.J., 1927) and presented in Table 1.

Soil water balance computation: Soil water balance components and equations for their estimation in different rice cultivation were adopted from Murty and Jha (2013).Input parameters in the water balance study were viz. supplied depth of irrigation water and rainfall depths. Crop Evapotranspiration, percolation beyond the root zone of crop and surface runoff were the outflow components. The change in field storage was represented by the change in the moisture content of soil after accounting for all components of water inflows and outflows. Different components of the soil water balance for CPR and SRI methods were accounted and can be presented by a generalized form as shown in Eq. 1:

$\mathrm{S}_{\mathrm{f}}=\mathrm{S}_{\mathrm{i}}+\mathrm{RF}+\mathrm{IR}-\mathrm{ET}-\mathrm{P}-\mathrm{Dr}$

Where,

$\mathrm{S}_{\mathrm{f}}=$ Water stored in the field at the end of the day $\mathrm{Si}=$ Water stored in the field at the start of the day 
$\mathrm{RF}=$ Rainfall for the day

$\mathrm{IR}=$ Depth of irrigation for the day

$\mathrm{P}=$ Amount of water lost through percolation for the day

Dr- Drainage (if any) during the day

ETc - Crop evapotranspiration for the day

In case of DSR method of rice cultivation, water balance equation is expressed similar to other upland crops as shown in Eq. 2:

$\mathrm{Mi}=\mathrm{M}_{\mathrm{i}-1}-\mathrm{RFi}-\mathrm{ROi}-\mathrm{Ii}-\mathrm{CRi}+\mathrm{ETci}+\mathrm{Dpi}$

Where,

$\mathrm{Mi}=$ soil moisture level on $\mathrm{i}^{\text {th }}$ day,

$\mathrm{M}_{\mathrm{i}-1}=$ soil moisture level on $\mathrm{i}-1^{\text {th }}$ day,

$\mathrm{RFi}=$ rainfall on $\mathrm{i}^{\text {th }}$ day,

$\mathrm{ROi}=$ runoff from the soil surface on day $\mathrm{i}$,

$\mathrm{Ii}=$ Irrigation depth on day $\mathrm{i}$ that infiltrates the soil,

$\mathrm{CRi}=$ capillary rise from the groundwater table on day i,

ETci $=$ crop evapotranspiration on day $\mathrm{i}$,

$\mathrm{Pi}=$ water loss out of the root zone by percolation on day $i$.

In present study, the groundwater level at experimental plot was about $18 \mathrm{~m}$ below ground surface, hence the capillary rise component was not considered in water budgeting estimations.

Crop evapotranspiration $\left(\mathbf{E T}_{\mathbf{c}}\right)$ : Evapotranspiration is the total water lost due to transpiration from a crop and evaporation from the soil for a particular area during a specified time. $\mathrm{ET}_{\mathrm{c}}$ is determined by the crop coefficient approach whereby the effect of the various weather conditions are incorporated into $\mathrm{ET}_{\mathrm{o}}$ and the crop characteristics into the $\mathrm{K}_{\mathrm{c}}$ coefficient (Allen et al., 1998). The following relationships shown in Eq.3 was used to calculate daily crop evapotranspiration,

$\mathrm{ET}_{\mathrm{C}}=\mathrm{K}_{\mathrm{C}} \mathrm{X} \mathrm{\textrm {ET } _ { 0 }}$

Where, $\mathrm{K}_{\mathrm{C}}$ is a crop coefficient and $\mathrm{ET}_{0}$ is reference evapotranspiration. To calculate reference evapotranspiration, CROPWAT 8.0 tool (FAO, 2006) developed by Food and Agricultural Organization (FAO) was used. CROPWAT assesses monthly, ten day basis and daily input of climatic data for calculation of reference evapotranspiration $\left(\mathrm{ET}_{0}\right)$ by using FAO PenmanMonteith equation. In the present study, daily reference evapotranspiration was estimated.

Surface runoff (Q): Rainfall in excess of bund height in the experimental plots was considered to be available for surface runoff from the experimental plots and represented by Eq. 4:

$\mathrm{Q}=\mathrm{R}-\mathrm{BH}$

Where, $\mathrm{BH}$ is the bund height $(\mathrm{mm})$ and $\mathrm{R}$ is the rainfall $(\mathrm{mm})$ reaching the surface

Further from this value of $\mathrm{Q}$, surface runoff volume

Table 1. Physical properties of the soil of the study area.

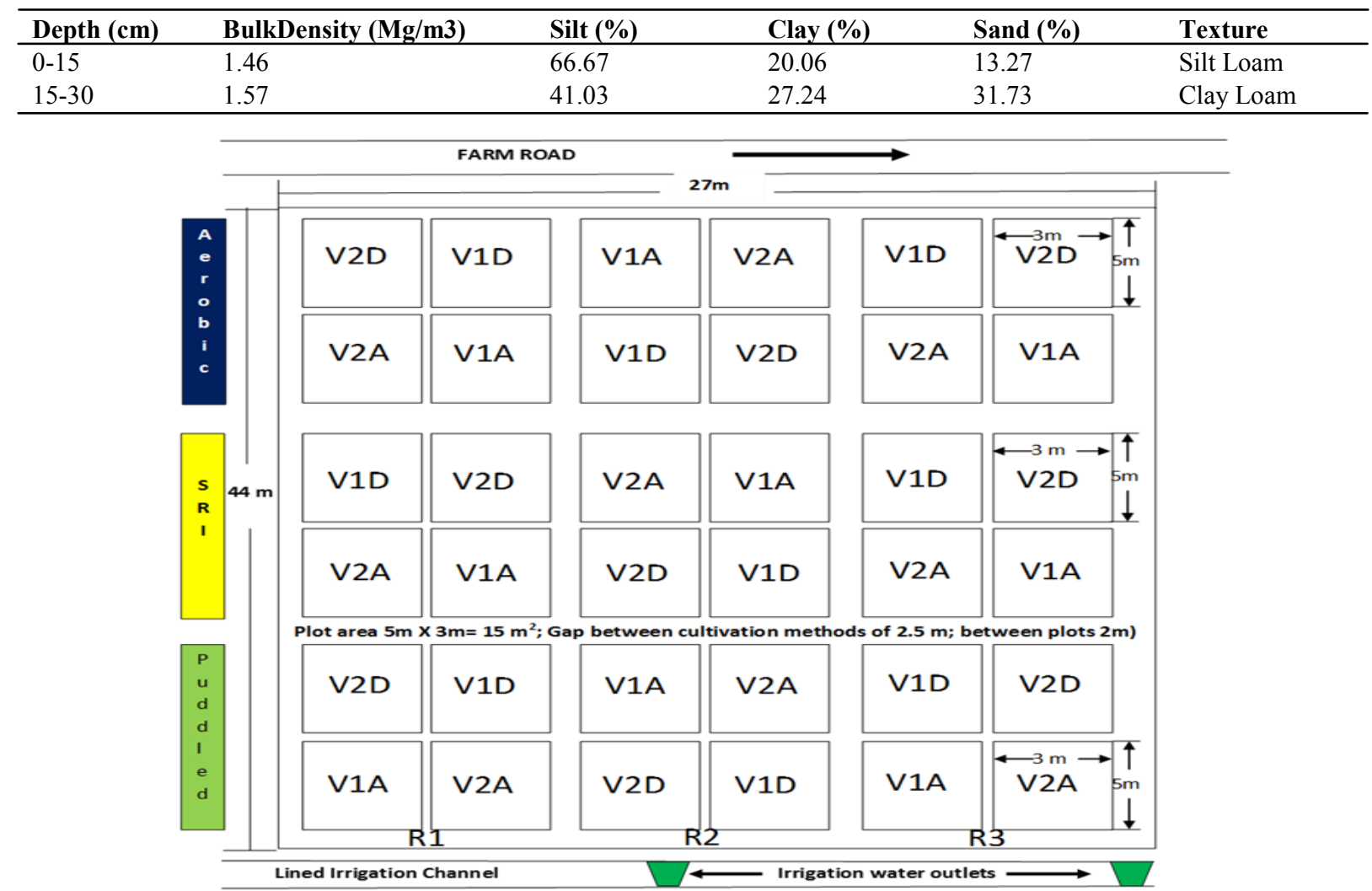

Fig. 1. Layout of the field experiment (V1,V2-rice cultivars under Adequate (A) and deficit (D) irrigation regimes under three replicarions ( $R 1$ to $R 3$ ). 
was calculated using the Natural Resources Conservation Service (NRCS) Curve Number (CN) method by using the $\mathrm{CN}$ of rice field to be 95 (Jung et al., 2012).

Deep percolation beyond the crop root zone: Percolation is the vertical downward movement of water through the soil surface. Percolated water is not available for use by the crop. The percolation rate of puddled rice fields is affected by a variety of factors such as soil texture, structure, bulk density, mineralogy, organic matter content and concentration of salts in soil solution etc. (Wickham and Singh, 1978). Percolation is governed by the hydraulic conductivity of the soil profile and the depth of standing water on the field. Because of puddling, the soil layer at the bottom of the root zone i.e. approximately $30 \mathrm{~cm}$ from surface gets compacted thereby reducing saturated hydraulic conductivity compared to that of non-puddled fields (Chowdaryet al., 2004). The reduction in saturated hydraulic conductivity caused by puddling was 5 to 6 times for silty clay loam soils (Singh, 2011). In the present study, Darcy's law was used to estimate daily percolation rate out of the root zone layer (Odhiambo and Murty, 1996; Singh et al., 2001) and is given by Equation 5:

$\mathrm{DP}=-\mathrm{K}_{\mathrm{s}}(\mathrm{dh} / \mathrm{dz})$

Where,

DP is percolation out of the root zone (mm per day);

Ks the saturated hydraulic conductivity ( $\mathrm{mm}$ per day); $\mathrm{dh} / \mathrm{dz}$ the head gradient $(\mathrm{mm} / \mathrm{mm})$.

Application of irrigation water: The irrigation water was supplied to different experimental plots though the network of High Density Polyethylene pipelines. Flow regulating valves were provided at regular intervals to ensure water delivery to each plot as per requirement. Volume of water to be supplied was calculated using the soil moisture deficit protocol before everyirrigation and the desired volume was supplied through pipeline network by using a digital water flow meter.

Irrigation scheduling for puddled rice is fixed such that irrigation will be given when the ponded water disappeared and it will be continued until depth reaches to $50 \mathrm{~mm}$. For SRI method of cultivation the irrigation was applied when hairline crack is developed in the field. In case of DSR method of rice cultivation, irrigation was applied when soil moisture content drops to $25 \%$ of available water and then it is filled up to the field capacity (FC) moisture content.

Weather data: Daily rainfall data along with other weather parameters was acquired from Agromet observatory of Division of Agricultural Physics, ICARIARI, New Delhi, which is located within a radius of $0.5 \mathrm{~km}$ from the experimental field. The weather parameters during the crop growing period was analyzed and used for estimation of reference evapotranspiration for subsequent use in water balance equation.

Water productivity: In crop production system, the water productivity (WP) is used to define the relation- ship between the grain yield and the total amount of water used in crop production, expressed as grain yield per unit volume of water (Ali et al., 2008). In this study, two different approaches were used for estimation of water productivity, such as:

Water productivity based on the crop evapotranspiration during the growing season was estimated using Eq. 6:

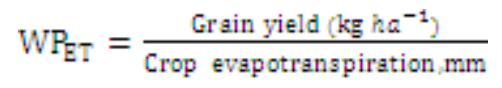

Water productivity based on depth of irrigation water applied during the growing season:

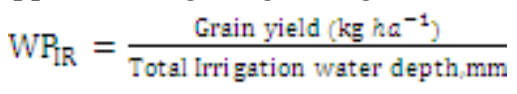

\section{RESULTS AND DISCUSSION}

Irrigation scheduling: The number of irrigation events in all three cultivations methods was more for year 2014 as compared to the year 2013 because of the occurrence of very high rainfall $(1203 \mathrm{~mm})$ in kharif 2013 against $395 \mathrm{~mm}$ in kharif 2014 during the crop growth period. Moreover, twenty one irrigation events amounting $1052 \mathrm{~mm}$ were applied in Conventional Puddled Rice (CPR) method during 2014 as compared to eleven events amounting $552 \mathrm{~mm}$ during 2013. Whereas, for System of Rice Intensification (SRI) method, eleven irrigations amounting $447 \mathrm{~mm}$ were applied in year 2013 and twenty irrigations amounting $809 \mathrm{~mm}$ in year 2014. However, for Direct Seeded Rice (DSR) method, only nine irrigation events amounting $367 \mathrm{~mm}$ was applied in year 2013 and 13 irrigations with total depth of $523 \mathrm{~mm}$ were applied during 2014. The irrigation scheduling i.e. depth and time of irrigation in all three methods of cultivation for years 2013 and 2014 is presented in Tables 2 and 3, respectively.

Water management: Amount of water required for different activities like land preparation, nursery raising and for providing irrigation during year 2013 and 2014 is shown in Fig. 2 and 3 respectively. It was observed from Fig. 2 that for year 2013 the amount of water supplied to raise nursery was $19.5 \mathrm{~mm}$ and 19 $\mathrm{mm}$ under CPR and SRI method, respectively. Whereas the depth of water supplied for land preparation was $30 \mathrm{~mm}, 175 \mathrm{~mm}$ and $160 \mathrm{~mm}$ for DSR, SRI and CPR methods, respectively. Also from Fig. 3, it was observed that for year 2014 the depth of irrigation water supplied to raise nursery was $20 \mathrm{~mm}$ and $22 \mathrm{~mm}$ for CPR and SRI method, respectively. Whereas the depth of water supplied for land preparation was $40 \mathrm{~mm}, 170$ $\mathrm{mm}$ and $180 \mathrm{~mm}$ for DSR cultivation method, SRI and CPR methods, respectively.

Crop evapotranspiration: The crop coefficient values of rice for different cultivation methods available from published literature (Chusnul, 2010; Choudhury et al., 2013) were used along with the estimated reference 
Sagar Dattatraya Vibhute et al. / J. Appl. \& Nat. Sci. 9 (3): 1373 - 1380 (2017)

Table 2. Irrigation scheduling of rice cultivars under three different cultivation methods during kharif 2013.

\begin{tabular}{llllll}
\hline CPR (Conventional Puddled Rice) & SRI & & DSR & \\
\hline $\begin{array}{l}\text { Days after } \\
\text { Transplanting }\end{array}$ & Irrigation Depth & $\begin{array}{l}\text { Days after } \\
\text { Transplanting }\end{array}$ & $\begin{array}{l}\text { Irrigation } \\
\text { Depth }\end{array}$ & Days after Sowing & $\begin{array}{l}\text { Irrigation } \\
\text { Depth }\end{array}$ \\
\hline 47 & 51.0 & 54 & 41 & 5 & 40 \\
50 & 51.0 & 58 & 41 & 58 & 41 \\
53 & 49.0 & 62 & 41 & 65 & 40 \\
56 & 50.0 & 65 & 41 & 71 & 41 \\
59 & 50.0 & 68 & 40 & 79 & 41 \\
62 & 51.0 & 71 & 41 & 83 & 41 \\
65 & 50.0 & 77 & 41 & 95 & 41 \\
75 & 50.0 & 82 & 41 & 100 & 41 \\
79 & 51.0 & 85 & 40 & 104 & \\
82 & 49.0 & 89 & 40 & & \\
85 & 50.0 & 91 & 40 & & \\
\hline
\end{tabular}

Table 3. Irrigation scheduling of rice cultivars under three different cultivation methods during kharif 2014.

\begin{tabular}{|c|c|c|c|c|c|c|}
\hline \multicolumn{2}{|l|}{ CPR } & \multicolumn{2}{|l|}{ SRI } & \multicolumn{3}{|l|}{ DSR } \\
\hline $\begin{array}{l}\text { Days after Trans- } \\
\text { planting }\end{array}$ & $\begin{array}{l}\text { Irrigation } \\
\text { Depth }\end{array}$ & $\begin{array}{l}\text { Days after } \\
\text { Transplanting }\end{array}$ & $\begin{array}{l}\text { Irrigation } \\
\text { Depth }\end{array}$ & $\begin{array}{l}\text { Days after } \\
\text { planting }\end{array}$ & Trans- & $\begin{array}{l}\text { Irrigation } \\
\text { Depth }\end{array}$ \\
\hline 6 & 51 & 5 & 40 & 4 & & 40 \\
\hline 9 & 50 & 11 & 40 & 7 & & 40 \\
\hline 17 & 51 & 16 & 41 & 19 & & 41 \\
\hline 21 & 49 & 24 & 41 & 27 & & 40 \\
\hline 25 & 51 & 28 & 40 & 32 & & 40 \\
\hline 28 & 51 & 31 & 41 & 40 & & 40 \\
\hline 47 & 49 & 34 & 40 & 48 & & 41 \\
\hline 50 & 50 & 37 & 41 & 66 & & 41 \\
\hline 53 & 51 & 57 & 40 & 73 & & 40 \\
\hline 56 & 50 & 60 & 41 & 81 & & 40 \\
\hline 59 & 49 & 64 & 40 & 86 & & 40 \\
\hline 62 & 49 & 67 & 41 & 94 & & 40 \\
\hline 64 & 50 & 70 & 41 & 103 & & 40 \\
\hline 67 & 51 & 74 & 40 & & & \\
\hline 71 & 50 & 78 & 41 & & & \\
\hline 74 & 50 & 81 & 41 & & & \\
\hline 77 & 50 & 85 & 40 & & & \\
\hline 81 & 51 & 90 & 40 & & & \\
\hline 84 & 49 & 94 & 40 & & & \\
\hline 88 & 50 & 99 & 40 & & & \\
\hline 92 & 50 & & & & & \\
\hline
\end{tabular}

Table 4. Estimated water balance parameters of rice during kharif 2013 and 2014.

\begin{tabular}{lllllll}
\hline Treatment & Rainfall & Irrigation & $\mathbf{E T}_{\mathbf{c}}$ & DP & Runoff & $\pm \Delta \mathbf{S}$ \\
\hline Kharif 2013 & & & & & & \\
CPR & 1203 & 552 & 547.4 & 963 & 268.6 & -24 \\
SRI & 1203 & 447.0 & 490.4 & 870 & 314.6 & -25 \\
DSR & 1203 & 367 & 480.8 & 367.2 & 757.8 & -35 \\
Kharif 2014 & & & & & & \\
CPR & 395.4 & 1052.0 & 622.1 & 831 & 17.5 & -23 \\
SRI & 395.4 & 809.0 & 555.9 & 674.5 & 0.0 & -26 \\
DSR & 395.4 & 523 & 537.6 & 332 & 0 & -48.8 \\
\hline
\end{tabular}


Table 5. Grain yield $\left(\mathrm{t} \mathrm{ha}^{-1}\right), \mathrm{ET}_{\mathrm{c}}$ based water productivity $\left(\mathrm{WP}_{\mathrm{ET}}\right)$ and irrigation water productivity $\left(\mathrm{WP}_{\mathrm{IR}}\right)$ in $\mathrm{kg} \mathrm{ha}^{-1} \mathrm{~mm}^{-1} \mathrm{of}$ rice cultivar PUSA-1460 during kharif 2013 and Pusa Sugandh-5 during kharif 2014.

\begin{tabular}{|c|c|c|c|c|}
\hline $\begin{array}{l}\text { Year } \\
\text { (rice cultivar) }\end{array}$ & Rice cultivation method & Grain Yield (t/ha) & $W P_{I R}(\mathrm{~kg} / \mathrm{ha.mm})$ & $\begin{array}{l}\mathrm{WP}_{\mathrm{ET}} \\
\text { ha.mm) }\end{array}$ \\
\hline & CPR & 4.40 & 7.97 & 8.0 \\
\hline 2013 & SRI & 4.82 & 10.8 & 9.8 \\
\hline (PUSA-1460) & DSR & 3.03 & 8.3 & 6.3 \\
\hline & CPR & 5.87 & 5.6 & 9.4 \\
\hline 2014 & SRI & 6.30 & 7.8 & 11.3 \\
\hline (Pusa Sugandh-5) & DSR & 4.27 & 8.2 & 7.9 \\
\hline
\end{tabular}

- Rainfall = Irrigation $\quad$ Nursery Raising $\quad$ Land Preparation

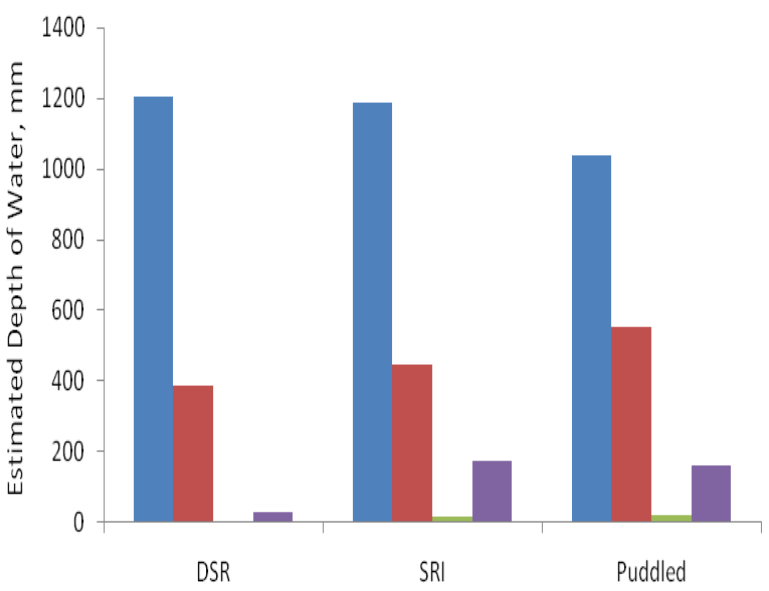

Fig. 2. Water budgeting components estimated for rice cultivar PUSA-1460 during kharif 2013.

evapotranspiration using modified Penman-Monteith formulae to obtain the crop evapotranspiration $\left(\mathrm{ET}_{\mathrm{c}}\right)$. Thus, the estimated actual evapotranspiration during the growing season for the year 2013 was $547.4 \mathrm{~mm}$, $490.4 \mathrm{~mm}$ and $480.0 \mathrm{~mm}$ and for 2014 it was 622.1 $\mathrm{mm}, 555.9 \mathrm{~mm}$ and $537.6 \mathrm{~mm}$ for CPR, SRI and DSR methods of rice cultivation, respectively. It was observed that the $\mathrm{ET}_{\mathrm{c}}$ under different rice cultivation methods were different and varied during the experimental period because of variation in evaporation component of the total evapotranspiration under these methods. In CPR method, due to existence of ponded water, the evaporation was observed to be highest followed by SRI and DSR methods. Similar trend inET $_{\mathrm{c}}$ was also observed by Linquist et al. (2015).

Percolation beyond the crop root zone: Different components of seasonal water balance for DSR, SRI and CPR cultivation methods for year 2013 and 2014 is presented in Table 4. It was observed from Table 4 that major portion of loss of water was observed in CPR and SRI cultivation methods because of percolation losses beyond the crop root zone. Whereas, in case of DSR method, the major loss was from surface runoff during kharif 2013 and due to ET $_{\mathrm{c}}$ during kharif 2014. Percolation beyond crop root zone was highest
-Rainfall = Irrigation = Nursery Raising = Land Preparation

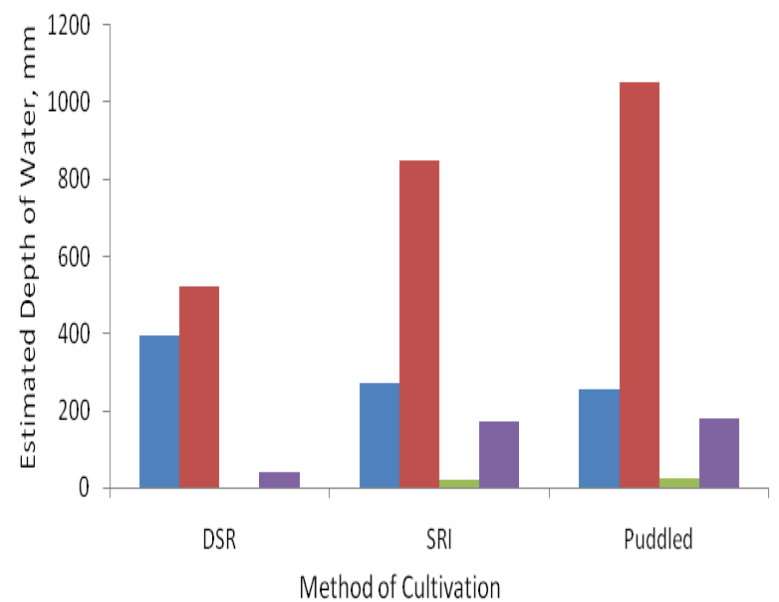

Fig. 3. Water budgeting components estimated for rice cultivar Pusa Sugandh-5 during kharif 2014.

for CPR method i.e. $55 \%$ and $58 \%$ for kharif 2013 and 2014, respectively. Percolation loss was lowest for DSR cultivation method i.e. $43 \%$ and $39 \%$ for kharif 2013 and 2014, respectively. In case of SRI method, it was $53 \%$ in kharif 2013 and $56 \%$ in kharif 2014. Dash et al. (2014) also observed that the in CPR method loss due to percolation was highest with $55 \%$ if input water was being lost through percolation beyond root zone.

Runoff: The runoff component has contributed considerable loss of water as outflow component during 2013 while it was negligible in 2014. During kharif 2013, very high rainfall (more than twice of annual average rainfall of the study region) accompanied with a few high intensity storm events resulted in higher runoff. Moreover in case of DSR, because of smaller bund heights, runoff was about $45 \%$ of total applied water for the year 2013. However, during the year 2014 no runoff was observed in SRI and DSR methods due to occurrence of only $395 \mathrm{~mm}$ recorded rainfall depth in the experimental area. Moreover, due to occurrence of a few high intensity rainfall events during kharif2014, the loss due to surface runoff was only $17.5 \mathrm{~mm}$ from the plots with conventional puddled rice method. The change in soil moisture storage $( \pm \Delta S)$ was also esti- 
mated and presented in Table. 4. It was observed that the $\pm \Delta \mathrm{S}$ was less in DSR method as compared to SRI and CPR methods of rice cultivation.

Crop yield and water productivity: It was observed that the grain yield was highest for SRI method in both the years 2013 and 2014. It was 4.82 tha $^{-1}$ in the year 2013 for rice cultivar Pusa 1460 and 6.30 tha $^{-1}$ in the year 2014 for rice cultivar Pusa Sugandh-5. In case of CPR method grain yield was 4.4 tha $^{-1}$ (PUSA-1460) and 5.87 tha $^{-1}$ (Pusa Sugandh-5) for year 2013 and 2014, respectively. The yield was lowest for DSR method with 3.03 tha $^{-1}$ in year 2013 for the basmati cultivar PUSA-1460 and 4.27 tha $^{-1}$ for the non-basmati cultivar Pusa Sugandh-5 during kharif 2014.

The water productivity pertaining to crop evapotranspiration and total irrigation water was observed to be highest in SRI method of rice cultivation during both years and for both cultivars. The irrigation water productivity ( $\mathrm{WP}_{\mathrm{IR}}$ ) of PUSA-1460 rice cultivar during kharif 2013 was highest $\left(10.8 \mathrm{~kg} \mathrm{ha}^{-1} \mathrm{~mm}^{-1}\right)$ under SRI method and there was no significant difference in the $\mathrm{WP}_{\text {IR }}$ for DSR $\left(8.3 \mathrm{~kg} \mathrm{ha}^{-1} \mathrm{~mm}^{-1}\right)$ and for CPR $(7.97 \mathrm{~kg}$ $\mathrm{ha}^{-1} \mathrm{~mm}^{-1}$ ) cultivation methods. Moreover, the $\mathrm{ET}_{\mathrm{c}}$ based WP (WP $\left.\mathrm{WT}_{\mathrm{ET}}\right)$ was highest for SRI method $(9.8$ $\left.\mathrm{kg} \mathrm{ha}^{-1} \mathrm{~mm}^{-1}\right)$ and lowest for the DSR method $(6.3 \mathrm{~kg}$ $\mathrm{ha}^{-1} \mathrm{~mm}^{-1}$ ). Similarly for the Pusa Sugandh-5 rice cultivar during kharif 2014, the $\mathrm{WP}_{\mathrm{IR}}$ was highest under DSR $\left(8.2 \mathrm{~kg} \mathrm{ha}^{-1} \mathrm{~mm}^{-1}\right)$ and lowest $\left(5.6 \mathrm{~kg} \mathrm{ha}^{-1} \mathrm{~mm}^{-1}\right)$ for CPR method of rice cultivation. Whereas, the $\mathrm{WP}_{\mathrm{ET}}$ for the same cultivar during 2014 was observed to be highest $\left(11.3 \mathrm{~kg} \mathrm{ha}^{-1} \mathrm{~mm}^{-1}\right)$ under SRI and lowest $\left(7.9 \mathrm{~kg} \mathrm{ha}^{-1} \mathrm{~mm}^{-1}\right)$ under DSR method. Yadav et al. (2010) also reported that the water productivity was more in case of DSR $\left(7.1 \mathrm{~kg} \mathrm{ha}^{-1} \mathrm{~mm}^{-1}\right)$ as compared to the transplanted puddled rice $\left(2.8 \mathrm{~kg} \mathrm{ha}^{-1} \mathrm{~mm}^{-1}\right)$. The estimated water productivity under different cultivation methods for both cultivars during kharif 2013 and 2014 is presented in Table 5 .

\section{Conclusion}

The water budgeting study concluded that the major loss of water was in the form of percolation beyond crop root zone followed by Crop Evapotranspiration $\left(\mathrm{ET}_{\mathrm{c}}\right)$. For System of Rice Intensification (SRI) and Conventional Puddled Rice (CPR) methods, more than $50 \%$ of the applied water through rainfall and by irrigation was lost due to percolation beyond the crop root zone only. The difference in $\mathrm{ET}_{\mathrm{c}}$ amount among three different cultivations methods was observed mainly due to varying amount of evaporation under different rice cultivation methods. $\mathrm{ET}_{\mathrm{c}}$ was highest in CPR followed by SRI and it was lowest for Direct Seeded Rice (DSR) method of rice cultivation. Water productivity estimates based on total irrigation water and $\mathrm{ET}_{\mathrm{c}}$ was observed to be highest for the SRI method of cultivation for both cultivars. Therefore, it could be recommended to adopt SRI method of cultivation not only to save water but also to enhance the water productivity. Nonetheless, the protocol developed for estimation of water budgeting parameters standardized in this study under three different rice cultivation methods can be replicated to other rice growing regions to develop judicious irrigation schedules and enhance water productivity under irrigated rice ecosystem.

\section{ACKNOWLEDGEMENTS}

Authors wish to acknowledge the financial assistance provided under the project funded by National Agricultural Science Fund (NASF) (Project code-DSS-2025), Indian Council of Agricultural Research (ICAR) to undertake this study at Water Technology Centre, Indian Council of Agricultural Research-Indian Agricultural Research Institute, New Delhi, India.

\section{REFERENCES}

Allen, R., Pereira, L. S., Raes, D. and Smith, M. (1998). Crop evapotranspiration: Guidelines for computing crop water requirements, Irrigation and Drainage Paper 56. FAO, Rome, Italy.

Ali, M. H. and Talukder, M.S.U. (2008). Increasing water productivity in crop production - A synthesis.Agril. Water mgmt., 95:1201-1213

Anonymous. 2016. First Advance Estimates of Production of Foodgrains for 2016-17.Ministry of Agriculture and Farmers Welfare, Government of India.

Angus, J.F. (1991). The evolution of methods for quantifying risk in water limited environments. In Muchow RC, Bellamy JA (eds) Climate risk in crop production: models and management for the semiarid tropics and subtropics. CAB international, Wallingford, Pp. 39-53

Bouman, B. A. M., Peng, S., Castaneda, A. R. and Visperas, R. M. (2005). Yield and water use of irrigated tropical aerobic rice systems. Agril. Water Mgmt., 74: 87-105

Bouman, B.A.M. (2007). A conceptual framework for the improvement of crop water productivity at different spatial scales. Agril. Systems, 93:43-60

Bouyoucos, G.J. (1927). The hydrometer as a new method for mechanical analysis of soil. Soil Sci., 23:343-353

Choudhury,B.U., Singh, A. K. and Pradhan S. (2013). Estimation of crop coefficients of dry-seeded irrigated ricewheat rotation on raised beds by field water balance method in the Indo-Gangetic plains, India. Agril. Water mgmt., 123:20-31

Chowdary, V. M., Rao, N. H. and Sharma, P. B. S. (2004). A coupled soil water and nitrogen balance model for flooded rice fields in India. Agriculture, Ecosystems and Environ., 103:425-441

Chusnul, A. (2010). Optimizing Water Management in System of Rice Intensification Paddy fields by monitoring technology, Ph.D. thesis, The University of Tokyo.

Dash, J., Sarangi, A., Singh, D. K., Singh, A. K. and Adhikary, P. P. (2014). Prediction of root zone water and nitrogen balance in an irrigated rice field using a simulation model. Paddy Water Environ., 13(3):281-290

Fagaria, N.K. 2007. Yield physiology of rice. Journal of Plant Nutrition, 30: 843-879

FAO. 2006. CROPWAT, a computer program for irrigation planning and management by $\mathrm{M}$. Smith. FAO Irrigation 
and Drainage Paper No. 26. Rome.

Jung, J., Yoon, K., Joe, D. and Lim, B. (2012). Water management practices and SCS curve numbers of paddy fields equipped with surface drainage pipes. Agril. $\mathrm{Wa}$ ter mgmt., 110: 78 -83

Li, Y. and Barker, R. (2004). Increasing water productivity for paddy irrigation in China. Paddy Water Environ.,2: 187-193

Linquist, B., Snyder, R., Anderson, F., Espino, L., Inglese, G., Marras, S., Moratiel, R., Mutters, R., Nicolosi, P., Rejmanek, H., Russo, A., Shapland, T., Song, Z., Swelam, A., Tindula, G. and Hill, J. 2015. Water balances and evapotranspiration in water $\square$ and dry $\square$ seeded rice systems. Irrig. Sci., 33:375-385

Murty, V. V. N. and Jha, M.K. (2013). Land and Water Management Engineering. Kalyani Publishers. Delhi.

Odhiambo, L.O. and Murty, V.V.N. (1996). Modeling water balance components in relation to field layout inlowland paddy fields. II: Model application. Agril. Water Mgmt., 30: $201-216$

Sandhu, S.S., Mahal, S.S., Vashist, K.K., Buttarb, G.S., Brar, A.S. and Singh, M. (2012). Crop and water productiv- ity of bed transplanted rice as influenced by various levels of nitrogen and irrigation in northwest India. Agril. Water mgmt., 104: $32-39$

Singh, K.B., Gajri, P.R., Arora, V.K. (2001). Modelling the effects of soil and water management practices on the water balance and performance of rice. Agril. Water Mgmt., 49: 77-95

Singh, K. B. (2011). Dynamics of Hydraulic Properties of Puddled Soils, Hydraulic Conductivity - Issues, Determination and Applications, Prof.LakshmananElango (Ed.), Pp. 29 - 49.Retrieved August, 282016 http:// www.intechopen.com/books/hydraulic-conductivityissues-determination-andapplications/dynamics-ofhydraulic-properties-of-puddled-soils

Wickham, T. H. and Singh, V.P. (1978). Water movement through wet soils. In: Soils and Rice. International Rice Research Institute, Los Banos, Philippines, Pp. 337-357

Yadav, S., Gill,G., Kukal, S. S., Humphreys, E., Rangarajan, R. and Walia, U. S. (2010). Water balance in dry seeded and puddled transplanted rice in Punjab, India. 19th World Congress of Soil Science, Soil Solutions for a Changing World, Pp. 43-46. 